University of Rhode Island

DigitalCommons@URI

Open Access Master's Theses

1975

\title{
A Student of Kant's "Second Analogy"
}

Kenneth John Bower

University of Rhode Island

Follow this and additional works at: https://digitalcommons.uri.edu/theses

\section{Recommended Citation}

Bower, Kenneth John, "A Student of Kant's "Second Analogy"'" (1975). Open Access Master's Theses.

Paper 1531.

https://digitalcommons.uri.edu/theses/1531

This Thesis is brought to you for free and open access by DigitalCommons@URI. It has been accepted for inclusion in Open Access Master's Theses by an authorized administrator of DigitalCommons@URI. For more information, please contact digitalcommons-group@uri.edu. 
A STUDY OF KANT'S. "SECOND ANALOGY"

BY

SEMNETY JOHN BONER

A THESIS SUBMITIED IN PARTIAL FULFIIIMTNT OF THE

REQUIREMEWTS FOR THE DEGREE CF

MASTER OF ARTS

IN

PHIIOSOPHY

UNIVERSITY OF_RHODE ISLAND

1975 


\section{ABSTRACT}

The ultinate ain of this essay is to explicate and Justify Kant's transcendental deduction of the category of causality. To put the matter simply, it seeks to shor that there are causal relations. Th1s is successfully accomplished if it can be shown, granting the empirical reality of time as a necessary condition of experience, that the empirical reality of causal relations is a necessary condition of the empirical reality of time.

This demongtration involves three steps. First, it is argued that the empirical reality of something permanent is a necessary condition of the empirical reality of time. (mis is preceded by an arguwont for the cla1in that time is a necessary form of intultion). This follows from the fact that the intuitive representation of time involves the Idea of a unity (1,e., tine) which remins numerically Identical despite the manifold of passing mowents contained in it. It is then argued that the enpirical reality of time involves the empirical reality of a phenomenon which embodies the property of numerlcal identity across tine, and wich, hence, is permanent. This is a fundamental contention of the "First Analogy." .

Secondly, it is argued that the empirical reality of metter is a necessary condition of the empirlcal reality of something permanent. This argument centers on the notion of a numerically identical object to which different appearances may be related. It is concluded that the possession of spatial relations is a necessary condition of the possession of numerical identity, and further, that being in space 
makes possible the distinction between the (permanent) object and its representation. This contention is contained, in modified form, in the second edition "Refutation of Ideal Ism."

Thirdly, it is argued that the empirical reality of causal relations is a necessary condition of the empirical reality of matter. Taking matter to be that which is capable of alteration, the argument focuses upon the concept of objective succession. It is contended that the concept of objective succession involves the notion of a necessary, or, irreversible sequence of representations, that is, a sequence determined by the object. Signiflcantly, the necessity of this notion does not follow by virtue of an analysis of the given concept of objective succession, but rather, stems from the need to add, in synthetic manner, a scheme, or, "supporting intultion," which will render the concept "serviceakle" in experience. The argument for causality is presented in the "Second Analogy."

By simple logical deduction, then, it is concluded that the empirical reality of causal relations is a necessary condition of the empirical reality of time. Given the fact of experience, and the empirical reality of time as its necessary condition, it follows necessarily that there are causal relations, which is what was to be proven. 
TABLE OF CONTENTS

\section{Page}

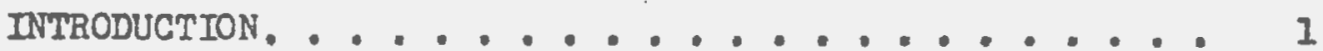

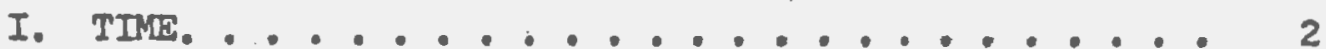

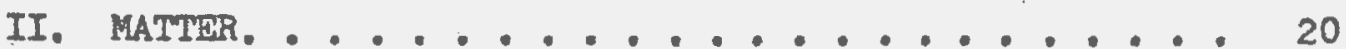

III. GaUSALITY ................... 47

CONCLUSION, ...................... 56

BIBLIOGRAPHY. .................. 60 


\section{INTRODUCTION}

Neither the proof nor the conclusion of the "Second Analogy" can be understood independently of certain conclusions contained in other sections of the Critique. The unity of the "critical philosophy" Is so thoroughly interwoven that any effort to comprehend an isolated section independently of the whole is futile. The Critique is no more a "patchwork" than the universe itself. On the other hand, the prospects of a detalled treatment of the whole is awesome. What follows is an attempt to present the basic unity of Kantian thought in such a manner as to preserve the richness of its detail. No single section so thoroughly reflects the unfty of Kant's thought as does the "Second Analogy." A thorough study of it will provide an excellent opportunity to grasp the essential strategy of the "critical philosophy." 
I. TIME

In the "Second Analogy" Kant has some important things to say about time. He observes that time, by itself, cannot be perceived. It is from this premise that much of his argument moves. ${ }^{1}$ Moreover, the "Analogies," in general, are offered as necessary conditions of the experience of objects in time. 2 A proper treatment of the "Second Analogy" must explain such statements. Consequently, the goal of this first section will be to present a unified account of those aspects of time upon which the transcendental deduction of the concept of causality is founded.

What did Kant have in mind when he employed the term "time"? It should be noted that this cerm is used in diverse manner, not only in ordinary talk, but also in technical scientific discourse. We might well begin by identifying and discarding some of these usages so as to clear the way for comprehension of Kant's meaning.

One often hears of "the effects of time," say, on one's attitudes, or on a society's institutions. One often hears the expression, "the time passed slowly." If one were a passenger on one of Einstein's speeding trains, "time" would not merely "seen to pass slowly" (so far as "seeming" is concerned I suppose, to the contrary, it might pass quickly), but, it is suggested, actually would pass more slowly? In

Immanuel Kant, Critique of Pure Reason, Norman Kemp Smith translator, (New York: St. Martin's Press, 1965), B234, B245. (Hereafter, all references to the Critique will be indicated by " $\mathrm{K}$ ".)

2 K, A177, B219. 
respectable philosophical and theological literature there is mention of the "beginning of time." Some have even sought to date the beginning. Prophets speak of "the end of time."

If we are to approach Kant's meaning, we must "purify" our 1dee of time. That 1s, we must consider it in abstraction from particular events. This "purified" 1dea which we seek is repeatedly referred to by kant as the pure. Intuition of time. Time does not produce effects. Attitudes may change, and institutions may corrupt, in time. But to speak of time, In the sense which Kant has in mind, as causing alteration in either montal or material objects is nonsense. Though things may pass in time, time, itself, does not pass. Hence, the quostion of whether it may pass more or less quickly, and under what conditions, is serfously lacking in meaning. The motion of the "hands" on one's clock, or even of the sun, itself, quicken, but this has no relevance to Kant's time. Finaliy, it is perfect nonsense to spoak of time as beginning or ending, for this implies that time "comes to be" or "passes away." That which "comes to be" or "passes avay," does so In time. Hence, wo should be committed to the absurdity that time "came to be" or "passed away" in time.

The Manifold of Time as Form of Intuition

Rant refers to time in the "Transcendental Aesthetic" as "a determinate form in which alone the intuition of inner states is possible." 3 Kant is asserting what he takes to be a synthetic 
a priori truth, namely, that it is impossible for one to have two wental states, neither of which is before the other. (Kant does not explicitly assert this, but he seems to bo comitted to this position). Th1s possibility, then, is not denied on grounds of formal logic; otherwise, the denlal would have to be taken es analytic. Presumably, Kent regards the thought of two mental states, netther of which is before the other, as poss1ble, albelt purely formal, or "empty." What is denied is the possibility of a corresponding intuition. From a subjective point of view we might express this impossibility by saying such a state of affairs is unimaginable, even if it is conceivable. However, the fact that this state of affairs is unimaginable must not be attributed to a weakness of the Imagination in the ordinary sense of the term. This inability is essentially different from one's inablilty to picture the face of a long-forgotten friend, or, say, one's Inabllity to picture in fullness a yand filled with fifty thousand apples. These latter Ilnitations are the concern of empirical paychology. The former, alone, is the concern of phllosophy. ${ }^{4}$ The latter are known as the result of experience. The former is known as a necossary condition of the possibitity of experience.

In Arlstotle's Metaphysics the law of non-contradiction is vindicated as a necessary condition of (determinate) meaning. It is not presented as an analytic truth which follows necessarily from a given concept of "meaning." It functions as a principle of differentia-. tion. I believe that Aristotle's distinction between "vindication"

\footnotetext{
4. Bl52.
} 
and "proof" is important to bear in mind when considering the objective validity of all of Kant's synthetic a priorl assertions. Note that Aristotle offers no proof of the lax of non-contradiction. He says Instead that those who seek proof for what is the ground of all proof show a lack of education.

I suggest the possibility of an analogous justification for Kant's clain that tive is the form of intuition of inner states. If one is to argue that two states are different (with respect to existence) and not merely parts of one complex state, they nust be able to 1dent1fy the particular relation which they, as distinct existences, bear. To argue that they night co-exist would present considerable difficulty in view of the fact that they lack spatial relations. If I have two qualitatively identical thoughts it is necessary that they exist at different tines (1.0.. one after the other) if I an to regand then as different. I should further mintain that, fron an objective point of view, it is just this difference of temporal position which constitutes their difference. This clain does not sten so much from an analysis of the given formal concept of "difference" as it does fron the bellef that the Idea of "different temporal position" is the only possible corresponding intuition that can be given to the formal relation of "difference," In the case of inner (non-spatial) states.

Let us now turn from the anifold of inner states to the nanifold of outer states (that 1s, states of objects in space). Spatial objects are constituted of tenporal relations. Any given object in space has parts wilch, in addition to having spatial relations, bear the temporal relation of co-existence. Furthermore, in an important 
passage, Kant asserts that only through the representation of time is the possibility of alteration (0.8., motion) rendered comprehensible.

"Only in time can tro contradictorily opposed objects weet in ${ }^{\text {other. }}$ ond the same object, namely, one after the

Our conclusion from the preceding is that the representation of a manffold of intuition, whether inner or outer, involves the representation of the manifold of time. When we speak of the manifold of time as form of intuition we refer to the notion that any manifold of intuition is necessarily constituted of temporal relations, whether they be relations of succession or co-existence.

The Unity of Time as Formal Intuition

Our next task is to consider time not merely in 1 ts aspect as form of intuition, but as formal intuition (1,e., pure object of Intuition). The clearest statement Kant akes of this distinction occurs near the end of the second edition of the "Transcendental Deduction."

"But space and time are represented a priorl not merely as forms of sensible intuition, but as themselves intu1tions which contain a manifold (of their okm) and therefore are represented with the determination of the unity of this manifold..."

In a footnote to this statement, there is contained what follows:

"Space, represented as object....contains more than mere form of intuition, it also contains combination of the menifold... In an intuitive representation, so that the form of intultion gives only a manifold, the formal intuition gives unity of representation. In the Aesthetic 
I have treated this unity as belonging merely to sensibility, simply in order to emphasize that. it precedes any concept, although, as a matter of fact, it presupposes a synthesis which does not belong to the senses but through which all concepts of space and time first become possible."6

Though the footnote refers specifically to space, obviously it may be applied to time. Kant has already sald that only through the representation of time is the possibility of contradictory states In one and the same object rendered comprehensible. It seems that something of a mutual relation exists here. That is, only through the representation of contradictory states of one object is the representation of time as formal intuition comprehensible. At no point does Kant explicitly state this. However, in the passage cited above he does say that the formal intuition of time presupposes a synthesis of the understanding which involves the representation of a manifold ( $1 . e .$, contradictory states) in one object (time, as formal intuition). The Idea of time as single object containing contradictory states is also present, at least implicitly, in the Aesthetic.

"Different times are part of one and the same time."7

Now I would like to introduce a terminology which does not use the same term to refer to both the part and the whole. I will refer to the "different times" as "moments," and "one and the same time time," as "time". Different moments are part of time.

"Different times are not simultaneous but successive." 8 Hence, time is constituted of moments which are successive.

6 K, B160。

${ }^{7} \mathrm{~K}, \mathrm{~A} 32$.

${ }^{8} \underline{K}$, A32. 
We have been told that time, as formal intuition, glves unity to the manifold (succession of moments). This relation between time and the manifold of moments must be made clear. Our question, then, becomes, in what sense does the representation of time provide unity to the manifold of moments? Or, what, sort of unity does the manifold of moments possess?

A manifold of particular moments might be unffied through the representation of the concept of "moment". The concept of "moment" would represent in unity all possible moments, that 1s, all possible particulars which might be subsumed under it. This, however, is not the sort of unity (let us call it a conceptual unity) with which we are concerned.

On the other hand, it is not correct to regard the unity of time as referring to the Idea of "the totality of all actual moments". One might represent in unity all the rocks in existence through the idea of the set of all rocks. But this again is an artificial unity, conceptual in origin. We do not grasp the nature of tine as formal intuition by thinking it as the set of all moments. In each case I have identified what might be called a merely conceptual unity. What I seek to express in contradistinction is a real unity. This is more closely expressed in the idea of time as a single identity manifest in each successive moment. I think we can further illustrate this distinction by way of reference to Hume's doctrine of the unity of the self. Recall Hume's reference to the self as a "bundle of perceptions". His purpose was to refute fustifications for the assertion that there was a single substance, or spiritual identity, of which 
each successive perception was but a modification. The only unity Hume would allow from 2 philosophical point of vlew was that mere conceptual unity expressed in the notion of "bundile." Now it is Kant's contention that time is not merely a bundie of moments. To the contrary it is a single object manifest in each successive moment. This essential idea is expressed in the opening statements of the First Analogy.

"All appearances are in time, and in it alone, as substratum (as permanent form of inner intuition). can either co-existence of succession be represented. Thus the time in which all change of appearance must be thought, remains and does not change." 9

Kant suggests the need to represent time analogically through the representation of "a Iine progressing to infinity, in which the manifold constitutes a serles of one dimension only, and we reason from the properties of this line to all the properties of time, with this one exception, that while the parts of the line are simultaneous, the perts of time are always successive." 10 Note that the varlous points on the line are not merely different, but, in addition, parts of one and the same Ine.

Now we have spoken of the "manifold of time" and of the "unity of time." Time contains a manifold of successive moments. Yet each moment is part of one and the same time. I think that this latter proposition is confirmed if it is the case that only through the representation of time as a "real unity" is the representation of the

\footnotetext{
9.

10 K, B50.
} 
manifold of time possible. That this is in fact the case can be seen through a closer examination of the relation of succession. What is necessarily involved in the representation of succession will be necessarily involved in the representation of the mantfold of time for the very fact which makes the noments in time different (hence, inifold) is that they are successive.

That two moments are different is a necessary but not a sufficient condition for their being successive. Two moments may be part of different times (as two points be on different lines). The existence of two times is here asserted as a possibility with respect to formal logic, hence I do not dens its impossibility given the conclusions of transcendental logic. The point to be made is that if two moments are successive, they are not merely different, but are different states of one and the same object.

A distinction may be dram between the ldea of "alteration" and that of "mere succession." In the ldea of alteration there is contained the 1dea of two states which are not only successive, but parts of one object. Kant, himself says so much. ${ }^{11}$ On the other hand, it may be that two phenomena are successive (say, two mental states) where there is no suggestion of an underlying substrate. In such a case we might say there was a succession, but no alteration. Note what A. H. Sinith has to say:

when think of change we think that it implies the contimance of something identical in that which is changing, and that in consequence it is necessary

11. 8233. 
to percelve something permanent when we are

consclous of change. But even if this were allowed...

it would still be necessary to recognize that change

is not the only form of time determination. There

is also succession. Nor in regard to succession it

is necessary to think of the continuity or permanence

of time itself, but it is not prima facie obvious that

it is necessary to think of anything else which is permaneat. "12

Succession mey be distinguished from aiteration in that the latter includes the idea of an object which persists in time, that is, the Idea of something permanent, or at least relatively permanent, which 1s not of course, time 1tself. Nevertheless, I submit succession must ultimately be understood as requiring a permanent, even if this is nothing other than time 1tself. If this is true, then, we are Justified in our contention that the representation of the unity of time (time as persisting, mumerical identity of which successive moments are so many manifestations) makes possible the representation of the manifold of time. To put the natter graphically, only through the representation of time as a persisting, numerical 1dentity, is the accompanying representation of time in 1 ts essential aspect as "flowing" possible. In short, the Idea of timo, as intuitive representation involves the Idea of a persisting, numerical identity, that is, a single object in which contradictory precicates are unified.

\section{The Empiricel Reality of Time}

Now that we have gone at some length to describe the idea of time as Intuitive representation, we mast confront the question of what

12 A. H. Smith, Kantian Studies, (London: Oxford University Press, 1947), p. 17. 
soxt of reality is to be attributed to time, To fump headfirst into the matter, we might answer that time is expirically real but transcondentally 1deal. Kant, hinself, employs these terms in the Aesthetic. To say that time is empirically real is to say that it is objectively valid with respect to all objects that may be given through our senses. 13 But what does 1 mean to refer to a representation as objectively valid? I take it that a representation has objective validity if it can be ascribed to an object, that is, if it is a condition or property of the object. Note that Kant denies absolute reality to time, here meaning that it is denfed that time is a condition or property of things apart from the conditions of the possibility of sensible intuition. This constitutes the transcendental 1deality of time. 14 But what is implicitly affirmed by the denial is that time is a condition or property of things given in sensible intuition. Now according to Kant, a representation be ascribed to an object if and only if one of two things is true. Elther the representation must make the object possible or the object amst make the representation possible. ${ }^{15}$ Time qualifies under the former condition, and hence, is sald to be a priori determinant of the object.

A paradoxical situation may be noted here. Time has been referred to, on one hand, as an object (an object for pure intuition), and on the other, a condition or property of objects (1.e.. objects of perception). But this is easily enough explained. To say that time is

13 ‥ B52.

$14 \mathrm{X}, \mathrm{B} 52$.

$15_{\underline{K}}, 8125$. 
a condition of the object is to say the object is temporal, or has a certain position in the temporal order. Reference to time as object suggests the temporal order itself within which the object has a position.

In general, it is a rule (technically, a postulate of empirical thought) that an object or 1ts properties exist (have empirical reality) only if they are possible perceptions. ${ }^{16}$ special problems accrue, however, if we apply this rule to time with respect to its empirical reality. Throughout the "Analogies" it is repeated that time, 1tself, is not perceived. ${ }^{17}$ What is perception? To understand th1s it will help to review some basic distinctions Kant has drawn in his analysis of experience.

We have, to begin, the term "intuition." Kant's initial definition of intultion states it is that through which a mode of knowledge is in Immediate relation to an object and to which all thought as a means is directed. ${ }^{18}$ "Intultion" has a systematically ambiguous meaning. It may refer to the act whereby the representation is appercelved, or 1t may refer to the representation 1tself. If we keep to the latter sense, we may follow Professor Hintikka in understanding intuition quite simply as a particular 1dea. ${ }^{19}$ What Hintikka has in mind is the opposition of a particular idea and a universal, that is,

$16_{\mathrm{K}}, \mathrm{B} 273$.

$17 \underline{\underline{K}}$, B219, В225, В226, В238.

$18 \underline{\mathrm{K}}, \mathrm{A} 19$

19 Jaakko Hintikka, "Kant on The Mathematical Method," In Kant Studies Todsy, I. W. Beck editor, (IaSalle, Ilisnoisı Open Court, 1969), p. 119. 
a concept. But particular ideas may be opposed, in addition, to mere sensations. A necessary and sufficient condition of particularity is the possession of a unique position in the spatio-temporal framework. Mere sensations, having no such position, are not intuitions. 20

Kant maintains that it is the human condition that objects of intuition are given through sensibility alone.

"Objects are given to us by means of sensibility, and it alone yields us intuitions." 21

One may recall with puzzlement that time, itself, is said to be an object of pure intuition, hence, not given through sensibility. Our apparent contradiction can be resolved if only we recognize Kant's multifarious use of that term "object". In the broadest sense of the term, one which includes whatsoever comes before the mind, time is an object. The term has a stricter sense in the above sentence, however, meaning that which exists in space and time. Paton explains away the problem thusly:

"Though space is here spoken of as an 'object', strictly speaking neither space nor time is an object. An object must be an appearance of things-in-themselves and nust be given in empirical intuition. Space and time are only conditions of objects, but we may call them objects by a kind of analogy." 22

Now let us consider the term "sensation". Kant identifies sensation as "the effect of an object upon the faculty of representation, so far as we are affected by 1t..." He goes on to say, "that intuition

$$
\begin{aligned}
& 20_{\underline{K}}, \text { B44. } \\
& 21_{\underline{K}}, \text { A19. }
\end{aligned}
$$

22H.J. Paton, Kant's Metaphysic of Experience, (New York: The Macmillan Company, 1936), Vol. I, P. 98. 
which is in relation to the object through sensacion, is entitled empirical."23 Empirical intuition, then, is an essential element in experience. 24

Experience presupposes the representation of something given in space and time. To say that something is given is to say there is sensation. To say, in addition, that it is given in space and time (and this alone indicates actuality or empirical reality) is to say there is intuition.

\footnotetext{
"Perception exhibits the reality of something in space; and in the absence of perception no power of Inagination can invent and produce that something. It fs sensation, therefore, that indicates a reality in space or in time, according as it is related to the one or to the other mode of sensible intuition." 25
}

We may understand perception then as the conjunction of sensation with the form of intuition, or, as synonomous with "empirical intultion."

As an exanple let us take, as a possible object of experience, a certain tree. In the representation of the tree there is contained a certain manifold of sense-data (i.e., certain patches of colors, textures, etc.). These things are sensations. But the tree is also represented as occupying a certain amount of space, moreover a particular part of space. This idea involves the pure intuition of space and the empirical intuition (perception) of that bit of space. The empirical intultion arises out of the conjunction of sensation and intuition. In

$23 \mathrm{~K}, \mathrm{~A} 20$.

$24 \mathrm{~K}, \mathrm{~B} 119$.

$25_{\mathrm{K}}, \mathrm{A} 374$. 
addition to these factors there is an elemont of recognition, which Involves judgment. But this is not our present concern. We have 1solated three factors, sensation, intuftion, and thought. When we speak of perception we have in mind the first two. When we speak of experience we have in mind all throe.

Now let us return to the original problem of explaining what is mant by the empirical reality of time. Neftrer timo, nor a moment In time, can be perceived. What is percelved, if anything, is something which occupies a moment. We have struggled to isolate the idea of time from the menagerie of experience and now have the difficulty of reintegrating it. There are tro directions which may be taken in solving this difficulty. To repeat, the difficultyis that of pinpointing those facts which constitute the expirical reality of time.

One direction is supplied by the idea that the assertion that time is not, by 1tself, percelved, Implies that time, with something else, is percelved. The other direction, a wore properone, I think, involves accepting that time cannot be percelved (the "by itself" is superfluous), hence, searches for something other than perceivability as constituting its reality. The former approach is taken by Paton.

"Does Kant mean we can be aware of space and time apart from all objects of experience? Certainly we cannot perceive empty time or empty space, he insists on this over and over again in the Analogies in regard to time... To perceive time and space, wust perceive things in time and space, and we get the ldeas of absolute or empty time and space only by ellimigating or thinking away objects in time and space."

26. J. Paton, Kant's Metaphysic of Exparfence, (In Tro Volumes: New York: The Macnillian Company, 1936). Vol. I, P. 113. 
Note the maner in which Paton so easily glides over the problem. Does Kant provide Paton with any warrant for speaking like this? Kant does speak of "empty time." 27 But to be true to the text, what is insisted on "over and over again" is not merely that empty time cannot be percelved, but that time, itself, cannot be perceived, Furthermore, with what right can Paton suggest that insofar as one perceives something in time, one perceives time. It would seem that if one perceives something in tine, one percelves something in time, rather than time. Is a Iinguistic convention being adopted? Are we to say that when I speak of the perception of a moment in time I simply mean the perception of something in time? Does Kant ever speak this way? It seems that he does in the Metaphysical Foundations of Natural

Science (again the passage concerns space; but the same point will apply to time).

\begin{abstract}
"Consequently, the space. In wich we are to set up experlence regarding motions must also be capable of being sensed, 1.e., must be indicated by what can be sensed; and this space as the sum total of all objects of experlence and. 1tself an object of experience is called empirical spece. Now, such space, if its motion is to be capable of ing percelved, presupposes again another enlarged material space in which it is movable, and this enlarged space presupposes just as well another, and 80 on to infinity." 28
\end{abstract}

If we allow ourselves to speak of the "perception of time" in this sense (and even then it is merely a part of time which we have in mind), we would have to understand time, in this context, as not only the form but the matter of intuition. This is probably more in accord $27 \mathrm{~K}, \mathrm{~B} 237$.

${ }^{28}$ Immanuel Kant, Metaphysical Foundations of Natural Sclence. James Ellington translator, (New York: The Bobbs-Merrill Company, Inc., 1970), p. 19. 
with the ordinary usage of the word. The adoption of the convention. is fine, but I don't think we thereby solve our problem concerning what constitutes the empirical reality of time.

I would like to attempt a different approach towards explicating the idea of the empirical reality of time. This approach, hopefully, will be clearer, more consistent with the terminology of the "Aesthet1c," and will provide a more illuminating foundation for further inquiry into the necessary conditions of the empirical reality of time.

First, I suggest that the idea that the empirical reality of time is constituted by its being a possible object of perception is an illusion under which we have labored. The empirical reality of time consists in its being a condition or property of empirical objects. 29 It is a very special sort of condition because it is intuited rather than percelved (It shares this quality with space). The fact that an object has a certain temporal position is const1tuted by the fact that it must be represented as such. It. must be recognized as being in time. And if this is so, then it must be further recognized that the moment which this object occuples bears a relation of succession to other moments, since time contains a manifold of successive moments, and since the object not only occuples a moment, but is in time. But the existence or empirical reality of other moments requires that there be an object which occuples or fills them. I think the reasons for this are expressed obscurely if one says eapty moments cannot be percelved, and if other moments exist, they must be filled, since only

$$
29 \underline{\text { K. }} \text {. } 352 \text {. }
$$


then may they be perceived (It being assumed that their existence means the possiblilty of being percelved). It is more in accord with the terminology of the "Aesthetic" to say that the existence of other moments requires the existence of objects since the empirical reality of time, or any part of 1t, consists in its being a condition of objects.

The existence of a mantfold of time, that is, a mantfold of successive moments requires the existence of a manifold of appearances which occuples the successive moments. But the manifold of moments is successive only if they are part of one numerically identical time. The empirical reality of this numerical identity (as was the case with the succession) requires an object which bears this condition, that 1s, something wh1ch 1s permanent, or, at least, relatively so. It is fust this sort of argument which I think Kant had in mind in these obscure opening remarks of the "First Analogy."

"Thus the time in which all change of appearances has to be thought, remains and does not change. For it is that in which, and as determinations of which, succession or co-existence can alone be represented. New time cannot by itself be perceived. Consequently, there must be found in the objects of perception, that is, in the appegrances, the substratum which represents time in general." 
II. MATTER

Our final conclusion of the first chapter was that the empirical reality of a permanent object (an object which retains its numerical identity in the succession of 1ts states) is a necessary condition of the empirical reality of time. We shall now attempt an inquiry into the necessary conditions of the enpirical reality of a permanent object with the hope of finding that any such object must be matter in space. Consequently, cne may as well regard this section as an attempt to offer explanation and support for Kant's proof of the existence of matter. Recall that Kant refers to his proof as transcendental in nature. A transcendental proof of the exlstence of matter 18 one which shows that the existence of matter is a necessary condition of the possibllity of experience. Now concerning these necessary conditions, we will argue fron two propositions considered in the first section:

1. The empirical reality of time is a necessary condition of the possibllity of experience.

2. The empirical reality of a permanent object is a necessary condition of the empirical reality of time. We will now seek the necessary conditions of the empirical reality of a permanent object (understanding that these necessary conditions are, ultimately, of the possibility of experience). Three more propositions are assumed:

3. The permanent object must exist in time.

4. The permanent object must be a possible object of perception.

5. All possible objects of perception are elther objects of Inner sense or outer sense. 
We w11l attempt to demonstrate that the permanent object must be in space, that is, material in nature. Our argument will take this besic form: The permanent object must elther be in me (inner sense) or outside me (outer sense). It can't be in me, hence, it must be outside me (1.e.. in space).

Before the presentation of this argument (1.e., Second Edition "Refutation of Idealism"), wo will attempt to clarify the meaning which the term "matter" possesses in the Kantlan framework. As is the case with "time," "matter" has a long history of diverse philosophical, scientific, and common use. An especially crucial 18sue is that of the relation between matter and consclousness. Closer considerations here will not only facilitate presentation of Kant's proof of the existence of matter, but w1Il provide some insight into the nature of the causal relation which is the subject of the thind chapter. Our strategy, then, is this:

1. To offer a four-fold distinction with respect to material objects in an attempt to isolate the purely material aspect.

2. To present the "4th Parallogism" wherein the relation of the material object to consciousness is explained.

3. To present some remarks aimed at reconciling alleged contradictions in Kant's doctrine of matter.

4. To present the 2nd edition "Refutation" which contains the proof of the existence of matter.

I begin my efforts to expose what is meant by "matter" by identifying four aspects of any given material object. 
A. The object as it is for pure thought.

In describing the object as it is for pure thought we ldentify what must be true of any object if it is to conform to the necessary conditions of pure thought. An object conforms to the necessary conditions of pure thought simply in being thought. When we answer the question, "what is the object as it is for pure thought," we generate the concept of an obfect-in-general. The pure concept of an objectIn-general is the necessary correlate to the transcendental unity of apperception. The object as it is for pure thought is simply a subject to which certain types of predicates aust be attributed. The pure thought of the object involves the representation, "I," (the thought that the object is being thought, or, what is ordinarily termed self-consclousness) and the representation of a fudgment through which the object is identifled, or represented in unity.

In the "Hetaphys1cal Deduction" Kant argues the categorles are necessary forms of judgment in general. In the "Transcendental Deduction" there is contained the "objective deduction." It argues from the premise that it must be possible to represent the manifold of the object in unity with a single " $I "\left(1, e^{\prime}\right.$, in a single selfconsclousness). This, it is said, necessarlily involves judgment (It, In fact, constitutes judgment), hence, the form of judgment, 1.e., the cetegorles, In this manner the objective valldity of the categories is claimed to be proven.

B. The object as it is for sensation.

In describing the object as it is for sensation one describes the 
object as it is presented in everyday experience to the individual percelving subject. It is a description of the object as it is for you and you alone. The properties of the object as it is for sensation are very much dependent on the physiology, perspective, and perhaps, even the psychological state of the individual perceiving subject. The object as it is for sensation is, in all its detall, essentlally private, or, subjective. Recall Plato's Theatetus where "Socrates" and "Friends" wonder what it means to know the object in Ilght of the fact that one and the same object appears differently to every percelver. Was Protagoras right? Recall the Heraclitean fudgment that no $\operatorname{man}$ can step into the same river twice (or even once). The world as it is for sensation is a solipsistic world. It is that partfcular flux wh1ch occuples your consciousness alone. It is also the object of naive coimon sense.

c. The object as it is for intuition.

In describing the object as it is for intuition, we Ignore those properties dependent upon the contingencies of physlology. The object as It is for intuition occupies a certain position in time and space wich is constituted entirely of relations. When the object is considered solely in terms of spatio-temporal location it is considered as it is for everyone. It is Kant's "matter." It is the phenomenal object with which Kant would hope true science should concern 1tself. That is asserted of the object as it is for intuition is true or false independently of the emplrical nature of any perceiving subject. Hence, its properties are such that no consclousness (possessed with 
the forms of space and time) of the object will contradict it. These properties (e.g., location) are not attributed to the object independently of consclousness-in-general, but (unlike properties attributed to the object as it is for sensation) are attributed independently of any particular consciousness.

D. The object as it is in itself (noumenon).

The thought of the object as it is in itself involves regarding the object in abstraction from those representations, the possibility of which, depends on the form of intuition and the physiological structure of sense. The thought of the object as it is in itself is indeterminate to the point of lacking real significance (no corresponding. intuition), though, insofar as it involves the pure thought of an object, it has a formal significance. It may be thought, not known, nor even 1magined, unless through schema understood as analogical. (I have no intention of considering the doctrine of noumenon. It is as unimportant to Kant's critical thought as it is important to his religions and ethical thought. It is irrelevant to the distinction between inner and outer sense, mental and terial existence, and, Iikewise, real and imaginary representations. If one wishes to pleture Kant's notion of experience as an effect generated by the dynamic interaction of a self and an object, neither of which are known as they are In themselves, and then accuse Kant of the sort of metaphysics, or illicit extension of categories, which he so brilliantly uncovers and criticizes, one will be in good company, but, nevertheless, wrong. The 
very dualism (of self and object) on which such an interpretation is based is explicitly doubted by Kant). I

With these distinctions in mind, let us turn to the "4th Parallogism." In this section a proof of the existence of matter is offered. In spite of the failure of the proof, the passage is important because of its inftial statements on the relation of matter to consciousness-ingeneral.

\section{4th Parazlogism}

In the "4th Parallogism" there is contained what is commonly referred to as the first edition refutation of idealism. Kant implicitly refers to it as such when he nentioned in the preface to the second edition that "the only addition, strictly so-called, though one affecting the method of proof only, is the new refutation of psychological idealism..." The "old" refutation is without doubt the argument of the "4th Parallogism."

Kant's fluid use of the term "1dealism" is notorious and it will help to set some distinctions out. In the "4th Parallogism" Kant is concerned with the proposition that outer appearances cannot be imnediately perceived (hence, their existence is doubtful). Those who matain this are called idealists. Explicitly excluded are those who deny the existence of outer objects (e.g... Berkely). ${ }^{3}$ Those who admit

$$
\begin{aligned}
& \mathrm{I}_{\mathrm{K}}, 1358 \text {. } \\
& \text { 2. Bxl. } \\
& \text { 3. A369. }
\end{aligned}
$$


the possibility of external objects which cannot be immediately percolved, hence, maintain that space and time exist independently of "us and our sensibility" are transcendental realists." Supposedly, idealists, then, are also transcendental realists. Notable examples are Locke and Descartes. In each case, however, some qualification may be rendered. Locke does at least offer an argumant intended to render certain the existence of outer objects;namely that the ideas in us must have a cause, and this is the therial object. The weakness of the argument is well-exposed by Berkeley and Hume. Descartes, too, in spite of his belief that outer objects cannot be immediately perceived has a certain notorious theological argument which amounts to the claim that did matter not exist, God would be a liar. God isn't a liar, hence, matter exists. Now no sooner does Kant offer a stralghtforward definition of "1deal 1sm," then he drops it in favor of "empirical idealism" a term which must be taken as synonomous. 5 Finally, in the second edition refutation there is mention of material idealism, problematic 1dealism, and dogmatic 1dealism. Material idealism."declares the existence of objects in space outside us to be merely doubtful and Indemonstrable or to be false and impossible." The former is the problematic 1dealism of Descartes, the latter, the dogmatic idealism of Berkeley. 6

There is an important distinction which the phrase "refutation of

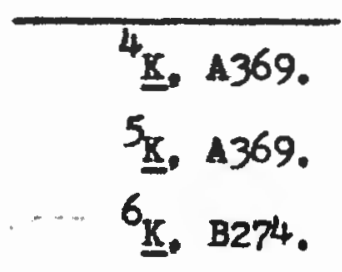


Ideal 1sm" obscures. It is one thing to refute the premises upon which a certain doctrine of idealism is grounded. It is quite another to peove to the contrary, that matter in space exists. Now the 4 th parallogism is an argument intending to prove that the existence of matter is doubtful. A successful criticisn of this pallogism need only involve a refutation of a premise upon which it is based. This criticism in itself might be called a "refutation of Idealism." It would not necessarily involve concluding, to the contrary, that "it is not the case that the existence of matter is doubtfur," or, "1t is the case that matter exists." Proof of these latter assertions might also be considered a "refutation of 1dealism," in fact, would probably be more deserving of the title.

The argument of the parallogism rests on the common doctrine that objects outside us cannot be immediately percelved because all that can be immediately perceived is what is in us. This was a popular preaupposition of the day shared by empiricists and rationalists alike which led to all sorts of shocking results ("1deas sent by God," "bundles of perceptions," "mon1sm," "windowless monads," "occasionalism"). It was left to Kant to offer his "transcendental idealism" as a means of destroying this havoc-wreaking notion. The key to Kant's Insight lay in revealing the ambiguity in the expressions "in us" and "outside us."7

Kant realized that the extermality of the object, that is, its existence in space, its materlality, could quite well be posited without augsesting the existence of an unpercelvable entity persisting

7 E. $1372-3$ 
independently of consclousness-in-general. For when it is asserted that only what is "In us" can be lamediately percolved, "In us" is to be taken in the transcendental sense as object or content of consclousness. But when matter in space is sald to be "outside us," it is to be taken in a completely different (empirical) sense, that 1s, in space. Yet even so far as it is in space, it 1s, in fact it must be, a possible object of consclousness, for space itself is merely representation. Hence, space and matter are transcendentally "In us," but -xpirically "outside us." The problematic ideal1sm of Descartes and Locke, then, was grounded on the notion that something in space can't be directly perceived. This in turn was grounded on the bellef that space was transcendentally real. By asserting, to the contrary, his om transcendental 1dealism, Kant removed the Husion under which his predecessors had labored.

But we must now ask ourselves what has been estabi 1shed? The parallogism has been exposed as employing a middle term equivocally. We can perfectly well speak of matter in space as being directly percelved, that is, there is no contradiction in asserting that wat is in space is yet in us. Kant has devastated the nost formidable and prevalent argument against the possibility of certainty with respect to the existence of matter. That is a good day's work. But it still remains for an argument to be constructed which would establish beyond doubt the fact that atter exists. Even granted that it is in accord with the nature of matter that it be directly perceivable, one may still consistently maintain that all such representations which seem to be outer are, in fact, Inventions of the inglnation. Kant's answer to 
th1s is perfectly clear, entirely plausible, yet lacking in any justification which would provide the absolute certalnty any philosophical truth should have. Kant argues that even imginary and dreamed objects are impossible apart from the perception of matter. His contention is that the a posterlori elements of such inventions cannot themselves be invented but must be provided in perception. Hence, inventions consist In the rearrangement of basic elements already provided in previous perceptions (an argument reminiscent of Locke). 8 That the elementary contents of Imaginary representations must have been perceived antecedently in experience is a plausible but unacceptable proposition. Though the refutation of the parallogism is insufficient to demonstrate the existence of matter, it contains an important contribution which Kant has made concerning the problem of the relation of matter and consciousness. Matter may be both in space and "in us," if space is "In us." Those who have difficulty swallowing the ldea that space is "In us" might find, upon closer examination, something equally curlous about the idea that space is "outside us." In either case, if one takes a literal interpretation of the spatial metaphor, then the whole issue becomes obscure. There is here a purely logical 1ssue. Space is "In us" if it is a content of our consclousness. Space is "In us" If it is an idea with no existence apart from the possibility of its belng an object for consciousness-in-general.

In light of Kant's analysis we return to the view that matter, or, the outer world is directly perceived. On the other hand, In spite

8, A374, 1375, A377. 
of this roturn to normalcy, it ought not be thought that Kant means to say that the outer reality of any representation can be immediately known or determined through perception. Kant says in the Prolegomena:

When an appearance is given us, we are still quite free as to how we should judge the matter. The appearance depends upon the senses, but the judgment upon the understanding; and the only question is whether In the determination of the object there is truth or not. But the difference between truth and dreaming is not ascertained by the nature of the representations which are referred to objects (for they are the same in both cases), but by. their connection according to those rules which determine the coherence of the representations in the concept of an object..."." 9

The empirical problem is that of determining whether a given appearance is real or not. The phllosophical problem is one of considering what the difference is between illusion and reality. It is a purely theoretical problem, and, even assuning it solved, the practical problem of making such judgrents in a particular case remains unaffected. ${ }^{10}$ Even a Kantian may be drawn to a non-oxistent oasis.

This being so, what advance has Kant made? Empiriclst philosophy was inclined towards the notion that the objectivity of a particular appearance consisted in its coherence with other appearances, and, more generally, with the totality of experience. Dlusions were "unmuly" and "Incoherent." Sone people aro unruly and incoherent, but they are, nevertheless, real. The "critical philosophy" has rejected the rational bankruptcy of empiricist thought without succumbing to the dogmatism of rationalist thought.

\footnotetext{
9 Immanuel Kant, Prolegomena to Any Future Hetaphysics, I. W. Beck translator, (New York: The Bobbs-Merrill Company, Inc., 1950), p. 38. $10_{\mathrm{K}}, \mathrm{A} 376$.
} 
While Kant was willing to admlt that the "strangeness" of a certain appearance might provide good grounds for refusing to belleve It is real, or material in nature, he would deny that this "strangeness" constituted its 1rreality. Kant simply intained that an appearance was real if it was in space, and not real if it wasn't. And this distinction was made without going beyond the possibility of consciousness.

Serious problems, yet, arise from the particular way in which Kant expresses his transcendental idealism. On the one hand, there is this sort of statement:

"This permanent cannot, however, be something in me... Thus perception of this permanent is possible only through a thing outside me and not through the mere representation of a thing outside me... representations themselves require a permanent distinct from them, in relation to which their change... may be determined."

On the other:

"External objects (bodies), however, are mere appearances, and are therefore nothing but a specles of $\mathrm{my}$ representations, the objects of which are something only through these. $f^{2}$ presentations. Apart from them they are nothing. "ill

The first statement comes fron the second edition. "Refutation of Ideal1sm." It sounds very different from earlier statements, like the second one, which comes from the first edition "Refutation" (1.e., "4th Parallog1sm.") H. W. B. Joseph identifies two interpretations of the second edition statement. He says that some see in it the "abandonment of the fundamental doctrine that our knowlodge is only of appearances, not of things by themselves." Others (N. K. Smith in

$$
\begin{aligned}
& 11_{\text {K, }} \text { B275. } \\
& 12_{\underline{K},} \text { A370. }
\end{aligned}
$$


particular), he says, "sees in its 'realistic theory of the independent existence of material nature' the ripening of the germinal ideas which give to the critical philosophy its real originality and value."13

We must reject the notion that Kant here means that the material object, or matter, is noumenal. To say this would contradict his most fundamental teaching. In all too many instances Kant makes it perfectly clear that matter as substance is phenomenal, not noumenal. Kant states explicitly that matcer is not a thing in itself.14

Even if it is conceded that matter is not noumenal, but phenomenal, the problem of reconciling the statements of both editions remains. N.K. Smith sees in the two passages a simple contradication which reflects a supposed continual wavering between subjectivism and phenomenalism.15 Something should be said here of Kemp Smith's method of interpretation. He works with the idea of the "patchwork theory" which holds that Kant changed his mind many times in the course of writing the Critique of Pure Reason and simply didn't bother to retract or erase what was written in the earlier parts. I submit the hypothesis that Kant, at times, used identical terms differently. It is, I think, preferable to the "patchwork" hypothesis. The fluid use of terms may very well have been intended for exegetical purposes, and also forced on Kant by shortness of time. 16

13H.W.B. Joseph, A Comparison of Kant's Idealism with that of Berkeley, (London: Humphrey MIlford Amen House, E.C., 1929) XV, p. 4. $14 \underline{R}$, A360, A373-4, A379, A359.

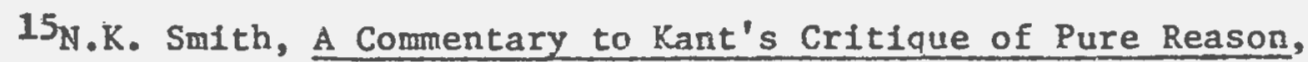
(New York: Humanities Press, 1950), Pp. 212-321.

16 $\mathrm{K}, \mathrm{Bx} 1$ ifi-xliv. 
With the distinctions of the first edition refutation in mind, we should be able to offer some beginnings toward a reconcillation. It seems natural enough to think that when he says representations require a permanent distinct from them, he is speaking of representations empirically in me. There are representations (empirically) outside me; namely, the permanent (that is, matter). Whether in me or outside me, the permanent is still representation.

We might attain a clearer statement of Kant's notion of the relation of matter and consciousness by focusing on the idea of the double-nature of appearances (the kind of representations relevant to this aiscussion). Let us suppose, as an example, that there is awareness of a material object, say, a tree. Supposing the awareness of a tree entalls supposing both a mental or subjective state of affairs, and a material or objective state of affairs. Locke and Descartes seemed to understand this distinction through a sort of camera theory analogy. The mind, as it were, is directly aware of a picture of the tree, but not the tree 1tself. This is the transcendental real ism which Kant rejects. It makes sense, really, only on the supposition that the mind is an individual thing in space, of course, nelther Locke nor Descartes viewed the mind as such. Referring to the position of Locke and Descartes (a position shared with Berkeley and Hume), N, K. Smith says:

"Knowledge is viewed as a process entirely internal to the Individual mind, and as carrying us further only in virtue of some additional supervening process, Inferential, conjectural, or instinctive. This subjectivism. also tends 
to combine with a view of consclousness as an ultimate self-revealing property of a purely individual existence.

For Kant both the mental and the materlal state were to be found with In the awareness of the appearance. Recall the distinction drawn between the object as it is for sensation and the object as it is for 1ntuition. In that context we could speak of the sensation and the intuition as distinct. But it was a logical distinction, a distinction of thought. The sensation and the intuition did not exist side-by-side In space, nor did they follow one another in time. They were both contained in the singular awareness of the appearance. The subjective status of the appearance is constituted by the fact that it is correlated to the unity of apperception at a certain time. Its objective status is constituted by the fact that it has a position in space at a certain time. The appearance, then, is both in the mind and in space.

When we acknowledge that the appearance is outside us, what do we admit as being outside us? We admit as objective only those aspects of the appearance which exist independently of my consciousness, though not independently of consciousness in general. ${ }^{18}$ The distinction between mo consciousness and consciousness-in-general is neither the same as, nor presupposes, the distinction between my personal self and the selves of others. To say the appearance (object) exists independently of my

\section{N. K. Smith, A Commentary to Kant's Critique of Pure Reason,} (New Yoris: Humanities Press, 1950), pp. 272-3.

${ }^{18}$ Immanuel Kant, Prolegomena to Any Future Metaphysics, I; W. Beck translator, (New York: The Bobbs-Kerrill Company. Inc.. 1950), p. 48. 
consclousness means the numerically identical object may be apprehended through other representations (which may or may not be qualitatively identical) at a time which may or may not be different. Representations of outer sense are unique in that a manifold of them may all be manifestations of one numerically 1dentical object. For example, you and I may see one and the same tree, in spite of the fact that we have qualitatively different representations (appearances), if our representations occupy the same place at the same time. A similar relation cannot be said of objects of inner sense. If we agree to close our eyes and imagine a tree, regandless of whether our respective appearances are qualitatively identical, neither numerical identify nor outer reality can be ascribed to them. What makes possible a numerical identity as opposed to qualitative identity, is the spatlal-temporal situation of the object. It is not possible for you to apprehend the same (numorically 1dentical) inner object that I apprehend, for the necessary conditions of the possibility of numerical identity are lacking. For this reason, the inner object (e.g., the object as it is for sensation) exists for my consclousness alone. The outer object (e.g., the object as it is for intultion), because it possesses the conditions of numerical identity, is a possible object for consciousness-in-general. When Kant speaks of matter as distinct from representations (in me) It is not Implied that ter is distinct from representation in genoral. Hence, to say also, that matter is a species of a representation involves no contradiction. When we admit the consciousness of an object in space we admit two facts. It is a fact that the object is apprehended at a certain time. The temporal determination, here, 
belongs to the approhension, not the object, hence, the empirical reality, which this fact indicates, is not that of the object, but the apprehension. The other fact to be adaltted is the existence of the object (in space and time). It, too, has its own position in space and time.

We must take note of the role which the spetiality of the object plays in constituting its objectivity. Why wouldn't temporality suffice for objectivity? For one reason, epace is the form of all outer intuition. This however is not a very revealing explanation. If we are to suppose that what is apprehended in a single consciousness exists apart from that consciousness (1.6., outside me), then we must suppose that the same object my be apprehended in a different consciousness. But in that case how are we to know that the same object 1s apprehended. That 1t.fits the sase description indicates only qualitative ldentity. Indiscernability does not constitute numerical identity. To know that two objects are numerically identical is to know they exist in the same place at the same time. ${ }^{19}$ This is not offered as an analytical truth. Rather it. is being suggested that only the ldea of Identical spatio-temporal location can provide the corresponding intultion required to render the formal concept of numerical identity serviceable.

Hopofully this argument provides reason for 1dentifyling what is "In space" with what is "outside " Rather than assuming that space is the form of outer intultion, we find that what is "outside us" 
(1.0., objective) must satisfy the necessary conditions of numerical identity in different consciousnesses (an object for consclousnessIn-general), and that this involves the possibility of ascribing a spatial (and temperal). Iocation. This connection is argued for in greater detall in P. F. Strawson's Individuals. 20

At this point it is interesting to compare Kant's situation with that of Berkeley. Berkeley eliminates the 1dea of matter, and, in so doing, eliminates the necessary conditions of there being a numerical Identity among different appearances. Within Berkeley's system the table I see and the table I feel are not one and the same. Ilkewise, the table I see and the table you see cannot be numerically identical. Berkeley manages to salvage the distinction between the subjective and the objective without the notion of matter by maintaining that subjective ideas are produced by us, whereas objective ones are caused by God.

Now what is the problem with Berkeley's system? In the first place, Kant would have quite a bit to say about the legitimacy and significance of Berkeley's extension of the category of cause to what seems to be a transcendent object. But I am interested in a more subtle line of attack. It is the argument of the second edition "Refutation of Ideal ism" that if one does away with matter (consequeritly, numerical ldentity)one also does away with the possibility of making temporal determinations, hence, ultimately, renders experience impossible.

20, F. Strawson, Individuals, (London: Methuen \& Co, Ltd, 1961), Part I. 
The Second Edition "Refutation of Idealism"

Let us first recapitulate a few points, Matter is a kind of representation. We may admit the objectivity and independence of matter (an Independence of any particular consciousness) without admitting the existence of anything independently of the possibility of consciousness-in-general. The terial object retains a numerical 1dentity in different consciousnesses, and the necessary condition of this is existence in space. The empirical reality of matter must consist in the fact that possible appearances are possessed with spatial relations which are the same for all possible consciousness. The spatial reality of the appearance is not given in sensation but posited in intuition. Hence the spatial reality of appearances should not be confused with the "spatial relations" which any appearance, even imagined ones, has for the individual consciousness. ${ }^{2 l}$. We now turn to Kant's proof for the existence of matter.

Kant begins with this proposition:

"I am conscious of my own existence as determined in tine." 22 A comparison may be drawn between this statement and Descartes' initial assumption in his proof for the existence of matter; namely, "I think, therefore, I am." In each case the philosopher assumes as Indubitable, what may be termed, his own existence. In neither case is It necessary for the sake of the argument to understend this as

\footnotetext{
21 A. H. Smith, Kantian Studies, (London, Oxford University Press, 1947), pp. 7-8.
}

22 K. B275. 
meaning there is a permanent, substantial or noumenal self, (though Descartes did, probably, have substantiality in mind). There is, though, an important difference. Descartes assumes the existence of the self. Kant assumes the existence of the self at a certain point in time. Thereas Descartes starts from the fact of self-consclousness, Kant starts from the fact of inner experlence. Kant, himself, notes

this crucial distinction:

"But In the above proof it has been shown that outer experience is realiy immediate, and that only by means of $1 \mathrm{t}$ is inner experlence -- not indeed the consclousness of my own existencer
tion of it in time -- possible, ${ }^{23}$

Sone commentators have missed this point and I think it is worthwhile to clearly mark the pitfall. Strawson, for example, says, in The Bounds of Sense, that the "Refutation" is "concerned with the general conditions of the possibility of self-consclousness." 24 Bennett' (Kant's Analyitic) makes the same error.

We might do well to point out other possible pitfalls. We rely on relatively permanent objects to measure the flow of time. But this is not at all what Kant is talking about. Prof. Walsh (Reason and Bxperience) questions Kant's argument for the existence of a permanent on grounds that it does not help us to measure the flow of time. 26

\section{$23_{\underline{X}}$, B277.}

${ }^{24}$ P. F. Strawson, The Bounds of Sense (London: Methuen \& Co, Itd, 1966). P. 125.

25Jonathan Bennett, Kant's Analytic (Cambridge: Cambridge University Press, 1966), p. 203.

26. H. Walsh, Reason and Experience (Oxford: Clarendon Press, 1947), p. 147. 
What must be made clear is that the emplrical reality of a permanent is not offered as a necessary condition for measuring the flow of time, but rather, as a necessary condition for the empirical reality of the flow of time. It is, after all, the existence, not the measurability, of time, which Kant takes to be a necessary condition of the possibility of experience.

Finaliy there are some difficulties with Paton's exposition, which, perhaps, owe their origin to the approach he took earlier with respect to the perceivability of time.

"The permanence of substance is presupposed by experience, and so is known a priori; but we must be able to find the permanent in actual experience and to discover examples of it by ordinary observation."27

The assertion that permanence can be discovered (and I take this to mean "established") by ordinary observation runs counter to the whole of Kantian thought. What can be established empirically cannot be established a priori. What can be established a priori cannot be established empirically. Paton's further assertion that permanence is verified in our observations of impenetrability or resistance is quite misleading. 28

Hume had long before demonstrated the inadequacy of this approach, and It was Hume's arguments which enabled Kant to see the need for a different approach (1.e., transcendental logic). Prof. Bennett elaborates quite nicely on the inability to establish permanence through observation. 29 Bennett's argument that across-time identity

27H.J. Paton, Kant's Metaphysic of Experience, (New York: The Macmillan Co., 1936), Vol. I, P. 98.

28 Ibid., p. 207.

${ }^{29}$ Johnathan Bennett, Kant's Dlalectic, (Cambridge: Cambridge University Press, 1974), p. 105. 
cannot be established through empirical means does not, however, mitigate against the contention that there is something which retains identity across time, nor, that this can be established a priori.

To return to the Refutation Itself:

"All determination of time presupposes something permanent in perception. Th1s permanent cannot, however, be something in me, since it is only through this permanent that my existence in time can itself be determined. $" 30$

The need for a permanent has already been considered in the first section of this thesis, and is argued for by Kant in the "First Analogy." If, then, Kant can show that the perception of a permanent in me is 1mpossible, he will have proven the possibility of the perception of a permanent outside me, that is, in space (for we already know the perception of a permanent is possible, and that if it is not in me, it must be outside me).

llant asserts repeatedly that in Innor intultion there is nothing permanent. His reasons, however, vary.

"In Inner intuition there is nothing permanent, for
the "I" is merely the consciousness of my thought."

Surely the fact that the "I" is merely the consciousness of my thought does not itself imply that in inner Intultion there is nothing permanent. Kant is here anticipating that some might think the indeterminate representation "I" to be a permanent intuition. He rejects this on the grownds that it is not an intultion at all. He does not, however, explicitly deny its permanence. In another passage he expresses

30, B275.

31 I. B413. 
reservation towards referring to the " $I$ " as abtding, an issue quite separate from that of whether it is an intuition, a concept, or merely a special, indeterminate signification.

For In what we call 'soul' everything is in continual flux and there is nothing abiding except (if we must so express ourselves) the 'I' which is simple 3 solely because its representation has no content..."

In another pessage Kant recognizes the distinction between the

Idea of its being ablding (permanent) and its being invarlably present.

"The ' $I$ ' is indeed in all thoughts, but there is not In this representation the least trace of intultion, distinguishing the 'I' from other objects of intuition. Thus we can; indeed percelve that this representation is Invariably present in all thought, but not that it is an abiding and continuing intuition, wherein the thoughts, 3 as being transitory, give place to one another,"

There are two approaches one can take in refuting the notion that the "I" provides the required content for the time-order. Prof. A, H. Silth expresses them quite well in his work. ${ }^{\text {*4 }}$. One can reject the notion that the "I" is a permanent intuition on the grounds that it is not an intuition at all. But there are some reasons for foregoing th1s approach. In the first. place, rejection of the "I" as being an abiding object given in intuition, not because it is not abiding, but because it is not given in intuition places too much welght on the fragile distinction between the "receptivity of sense" and the "spontaneity of thought." Why does time require a "given" permanent

\footnotetext{
32, 1382

$33_{\text {I. }}$ A 350 .

${ }^{34}$ A. H. Smith, Kantian Studies, (Londons Oxford University Press, 1947), pp. $39-40$.
} 
rather than a "supplied" permanent? Secondly, even if the "I" is ruled out as being a permanent intuition in me the possibility of there being a permanent in me st1ll remains. One might argue for the permanence of consclousness in which the "I" among other things is invariably or variably present. For example, there is the argument that you would not remember what happened to you yesterday were you not the same person. Kant shows this inference to be invalid, yet the possibility of its truth remains. 35 . It is also possible that some concrete sensedatum $(\theta .8 .$, a pain) might be present throughout one's experience.

A more fundamental approach involves the recognition that neither the "I" nor anything in me can provide the permanence required for the time-order because, not being in space, they lack the conditions of mumerical identity. The idea of numerical identity is Intrinsic to the Idea of permanence. That which persists retalns its numerical 1dentity. It was after all "numerical 1dentity" which was demanded by the existence of time. "Permanence" became involved only because an object which retains identity, across time has permanence.

That this approach is sound, and that Kant had it in mind are separate issues. I tend to think that he did, but not all that clearly. In one passage he explicitly asserts that only what is outer can have relation to a permanent, but, he merely asserts $1 t .36$ In the "Amphiboly" section he has a little more to say. ${ }^{37}$ There it is suggested that two objects may be qualitatively identical, but

$$
\begin{aligned}
& 35_{\underline{K}, A 364 .} \\
& 36_{\underline{K},} \text { A381. } \\
& 37_{\underline{K},} \text { A263-4. }
\end{aligned}
$$


mumerically different if they have different spatial positions at one and the same time. The numerical difference of objects is given by space 1tself, he says; It seems natural to think that he would also regard the numerical identity of objects as being given by space. There is also an important statement in a footnote to the preface of the second edition, wich, I think, contains the key to an understanding of the argument, yet has been for the most part ignored by Engl ish-speaking commentators.

The representation of something permanent in existence is not the same as permanent representation. For though the representation of (something permanent) may be very transitory and varlable like all our other representations, not excepting those of tter, it jet refers to something permanent."

Let us take a series of conscious states as constituting what might be referred to as "a continuous stretch of consclousness." Suppose that there is a certain sense-datum qualitatively identical in each successive state. What would it mean to say a single sense-datum persisted throughout, rather than, say, in each successive state there was another sense-datum fust like the one before? To assert the permanence (1.e., numerical identity) of the representation over and above its being invariably represented nould involve giving it an existence independent of its occurrence in thought (1.0., existence In spece). Consequently, It would involve the existence of matter. What if one argues that the "self" can provide the required permanent? Let us suppose successive representations occur. If we focus on their subjective aspect we may refer to them as successive ${ }^{38} \underline{\underline{K}}, \mathrm{BxZ1}$. 
states of one self in one time. Our idea of "one self", however, requires a corresponding intultion. We cannot employ the permanence of one's body to establ ish reference for the ldea of a permanent self, for that would involve admitting the conclusion (that matter exists) that one sought to escape by raising the spectre of a permanent self. Yet apart from such reference the ldea of a permanent self becomes erpty, giving rise to illusion. Strawson explains the nature of the illusion as a confusion of the unity of experience with the experience of unity.

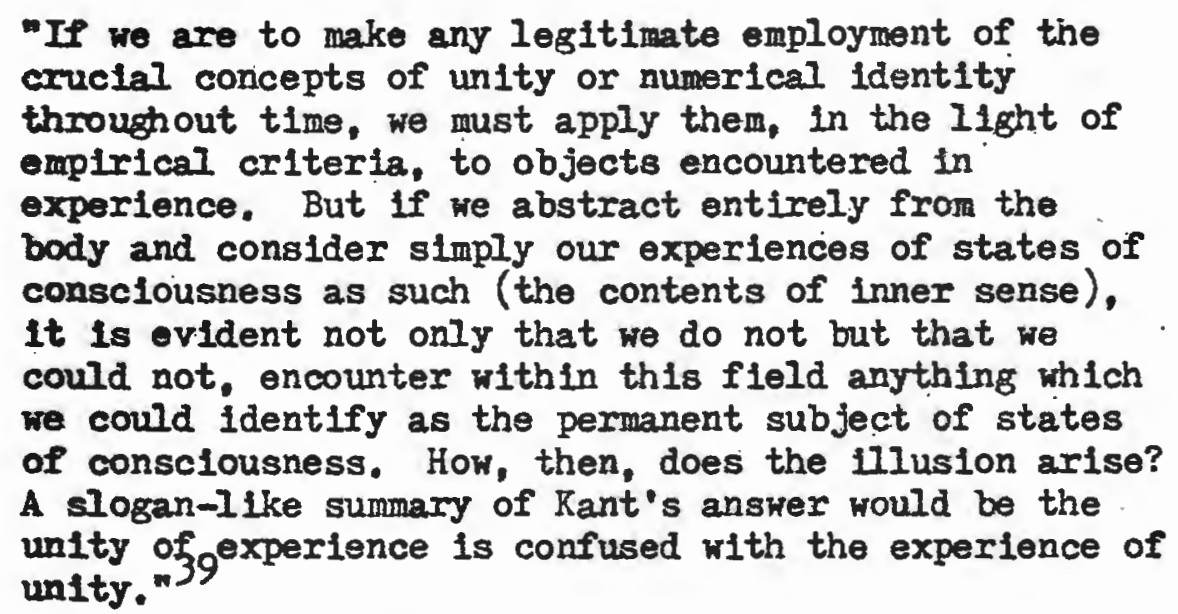

It must be maintained for the success of the argument of the "Refutation," not only that there is no perception of a permanent self, but that there can be no such perception. Kant realized, like Hume, that all introspective efforts produced only more representat1ons. The idea of a permanent self distinct from the transitory states is empty. It is the emptiness of the concept of self which

\footnotetext{
39. F. Strawson, The Bounds of Sense, (Londont Methuen \& Co, Itd, 1966), p. 37.
} 
provides the basis for our assertion that a permanent self is not a possible object cf perception.

Let us now consider the successive representations in their other aspect as being states of one object. Can a corrosponding intuition be given to the idea of a single object distinct from successive representations of it? The answer is yes. The successive representations are accounted for through qualitative description of their inner nature, and, further, through the recognition of their being successively apprehended. We can supply a corresponding intultion to the ldea of a permanent object to which the representations are related through the 1dea of matter in space. 


\section{CAUSAIITI}

We turn now from efforts to establish the existence of matter to the question of the necessary conditions of the existence of matter. Our aim is to establish that the concept of causality is among these necessary conditions. Two propositions, if assumed, w1ll hasten our arrival at this conclusion:

1. The possibility of the experience of atter is a necessary condition of the existence of matter.

2. The possibility of motion is a necessary condition of the existence of matter.

Nothing new is contatned in the idea of the first proposition. It is merely a specific application of the "critical" doctrine which limits phenomenal reality to that which may be object of experience. Ths second proposition is a specific application of the general doctrine that substance, as the permanent, is capable of alteration. Kant will further argue:

3. Only substance is capable of alteration. 1

4. Hatter is the only possible substance. 2

5. All material alteration may be reduced to motion. 3 Our argament, so far as I can see, does not rest on the truth of these last three assertions.

İ. B233.

2Immanuel Kant, Metaphysical Foundations of Natural Science, James Ellington translator, (New Yorks The Bobbs-Merril I Company, Inc., 1970), p.103.

Ibid., p. 14 . 
A necessary condition of the possibility of motion, as phenomenal real 1ty, is that 1t, too, must be a possible object of experience. Hence, we conclude that the possibllity of the experlence of motion is a necessary condition of the existence of matter. In the light of this analysis we may reformulate our Inquiry thuslys What are the necessary conditions of the possibility of the experience of objective succession? (Naturally, what can be sald of objective succession will be applicable to material alteration, or motion, since the latter is a species of the former). It is precisely this question which is the topic of the "Second Analogy."

Recall that our enquiry is intended to produce synthetical rather than analytical knowledge. An explication of the given concept of "the experience of objective succession" would identify necessary conditions of the possibllity of the experience of objective succession. But we are not satisfied with the generation of tautologies. Rather than analyze the concept in question, it is Rant's strategy to add properties which qualify as necessary conditions independently of purely logical considerations $\left(1, e_{\text {, }}\right.$ formal logic). What we are about to do, then, is not proceed from a definition, but rather, contribute to the construction of one. Kant, like Aristotle, belleved that "reel definitions" should come at the end of enquiry, not at the beginning. It will be helpful to consider Kant's notion of "real definition," in conjunction with that of "possibility."

-I here mean real definition .- which does not merely substitute for the name of a thing other more intelligible words, but contains a clear property by which the defined 
object can always be known with certainty, and which makes the explained concept serviceable in application, $\mathrm{n}^{4}$

We demand in every concept, first, the logical form of a concept (of thought) in general, and secondly, the possibility of giving 1t an object to which it may be applied. In the absence of such object, it has no

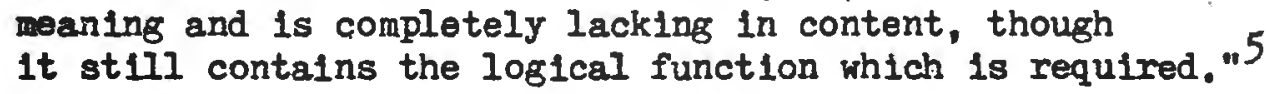

"The possibility of a thing can never be proved merely from the fact that its concept is not self-contradictory, but only through 1 ts being supported by some corresponding intuition." 6

Now it is necessary for the possibility of the experience of objective succession not only that we have a concept of objective succession, but that this concept be "meaningful" or "serviceable." It must have in addition to a formal sense, a real sense. The concept of succession, or successive status, in itself, presents no problem. Ne1ther does the concept of a subjective succession. To say that two representations were subjectively successive is to say they were approhended in succession (1.e., at different points in t1me). To say that $A$ preceded $B$ subjectively (where $A$ and $B$ are representations) means $A$ was apprehended first, and $B$ second. But suppose we say of $A$ and $B$, not that one was apprehended before the other, but that, objectively speaking, one preceded the other. Suppose that $A$ and $B$ were states of one object. What would it "mean" to say they were objectively successive rather than co-existent? From a purely formal point of view there is no

\footnotetext{
${ }^{4} \mathrm{~K}, \mathrm{A242}$

5. B239.

6 K. B308.
} 
problem. To say $A$ and $B$ are obfectively successive implies that $A$ and $B$ are predicates (in a relation of succession) of the object. But Kant demands "serviceability" of our concepts. Our concept as It stands does not provide us with the ability to identify any possible manifold of intuition as an objective succession. The inadequacy of the given concept can be seen through consideration of an example Kant, himself, provides.

Kant mentioned the situation where one apprehends, in succession, the successive positions of a boat going down a river. The recognition of motion must involve something other than the recognition that the manifold of states are apprehended in succession. For in a situation where one observes a house one may apprehend the manifold of states (parts of the house) in succession, and, while they recognize this fact, they nevertheless recognize the various parts of the house co-exist. The appearances which occur successively in me co-exist in the object. ${ }^{7}$ Now the serviceability of the concept demands a schema over and above our formal relation. Or, from another perspective, to establish the possibility of an objective succession we must be able to establish some supporting intuition. Our supporting intuition could, logically speaking, be anything so long as it was an intuition and provided the needed support. Professor Walsh, in a figurative explanation of Kant's point that time is not percelved, tells us that events do not come with their dates stamped on them. 8 If they did,

$$
\text { 7‥ B235-7. }
$$

8W.H. Walsh, "Kant on the Perception of Time," in Kant Studies Today, L.W. Beck editor, (LaSalle, Illinois: Open Court Publishing Co., 1969), p. 160. 
the dates, themselves, could provide our noeded intuition. Appearances are objectively successive when they have different dates stamped on them, and objectively co-existent when they have identical dates. Unlike other empirical properties of objects, however, temporal position is not sensibly indicated.

The empirical factor which Kant turns to instead is the subjective succession itself, that is, the sequence of representations. He argues that saying a manifold of appearance is objectively successive means that the order of the sequence of representations is irreversible or necessary. 9 There is no doubt that the idea of a necessary sequence. of representations constitutes a needed corresponding intuition. In one suift step both the serviceabllity of the concept and the possibility of the "thing" (1.e., the objective succession) is established.

One right wonder how we are to know when a sequence of representations was tiruly "Irreversible." Th1s, however, is a separate issue. Even if we fail to answer this question, we have succeeded in giving "meaning" to the concept of objective succession.

It still remains to make clear this "meaning" which has been given. Exactly what are we committed to when, in this context, we assert the sequence of representations to be necessary or irreversible? And how does the concept of causelity fit in? What, here, is the cause, and what is the effect? And precisely what is the objectively valid synthetic judgment in which the reality of a necessary connection in time is asserted?

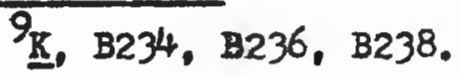


To begin, Kant wants to say that insofar as we regard our successive percoptions as constituting the apprehension of an objective succession we must regand the order of our perceptions as determined by the object. ${ }^{10}$ Saying the onder of perceptions is determined by the object mears, given the fact of the apprehension of the object, the fact of that particular order of perceptions follows necessarily. In saying that the order is irreversible, then, we are not making a statement about one's psychical history, but rather, the object. For exampie, suppose again, the boat going down the river. Given that I apprehend the boat at one position in the river, it does not necessarily follow that I will apprehend it in its next position. I might first be struck dead by Iightning. What we wish to say is that given apprehension of the boat going down the river the sequence of representations is imeversible. And even with this further stipulation we still maintain the judgment is synthetic. We concede as analytic, the fudgment that the apprehension of objective succession Involves a sequence of representations, but we insist that the "Irreversibility" is a predicate synthetically added. And, as the argument runs, it is justified a priori, for it makes possible the objective succession. This does not mean the liea of irreversibility produces the objective succession "so far as existence is concermed... but that only through the representation is it possible to know anything as object. " 17 .

$$
\begin{aligned}
& \text { 10, A108, Al91. } \\
& 11_{\text {K. }} \text { A92. }
\end{aligned}
$$


What is being said, in a nutshell, is that the proposition that, " $A$ state of affairs which is objectiveiy successive can be apprehended in only one order," is true, but not analytically true. No logical contradiction obtains from its denial. Rather than a logical justification we offer a transcendental one which consists in the assertion that, were this not true, the concept of objective succession would lack real significance, that is, serviceability. Hence, an objective succession would be theoretically impossible as phenomenon, for we would lack the means to 1 dentify $1 t$.

We have, then, a synthetic judgment. Given apprehension of an objective succession, the sequence of representations is irreversible. We may reformulate this in terms of the object alone. Given any objective succession, the sequence of possible representations is 1rreversible. Here "possible" indicates those determinate possibilities which constitute the empirical nature of the object.

In this synthetic judgment we have the idea of causality ("something from which we can conclude to the existence of something else"12), and the 1dea of a necessary connection in time. We have the object 1tself as cause and the Irreversible sequence as effect. ${ }^{13}$ The necessary connection in time is not between cause and effect but between the representations, all of which come under the heading of effect.

We have argued that the 1deas of an objective succession and a

$$
\begin{aligned}
& 12 \text { X, } 1243 . \\
& 13 \text { X, A205. }
\end{aligned}
$$


subjective succession are distinct. Our immediate purposes within the discussion of the "Second Analogy" were satisfied when we introduced to the concept of irreversibility as a necessary element of objective succession. But apart from this element of pure thought there is an element of pure intuition, likewise, involved in making the distinction. Objective representations are distinguished froll subjective representations not only by the fact that the former are thought as necessarily connected in time but also by the fact that the former are intuited in space. It would be wrong to think, then, as some have suggested $\left(e .8 . . \mathrm{Ca} \mathrm{Id}^{14}\right)$ that the thought of the representations as necessarily connected is equivalent to the thought of them as objective. While it is a necessary condition, it is not a sufficient condition. If this intuitive element is forgotten in the account of Kant's idealism it becomes quite easy to confuse it with the Idealism of Berkeley or Hegel. Consequently, though we hold that the thought of a manifold of representation as objective involves the thought of them as necessarily connected, the reverse relation does not hold. That the order of representations is necessary does not imply it is objective. Their necessity might result from the fact of divine causality. (Thus Kant may accept this notion of Berkeley's and still. wonder where in lies objectivity, which is something this notion was supposed to explain). Their may be laws which govern our mental history. The fact of objective change for Kant, then, is not constituted

${ }^{14}$ Edward Caird, The Critical Philosophy of Immanuel Kant, (New York: Kraus Reprint Co., 1968); P. 568. 
by the fact of necessity of connection. There must be further Involved the irreducible and inescapable element of being in space. 
CONGLUSION

If the argument of the third section is correct, then the concept of causality is objectively valid, which is to say, it makes experience possible. Assuming the fact of experience (and this is not to assume metter as the object of that experience, for it may be purely inner) then, It follows necessarily that there are causal relations. This is what we desired to prove from the outset.

By way of conclusion, something ought to be sald concerning the distinction between the causal connection which Kant has shown to be 2. necessary condition of the possibility of experience and those alleged causal connections which are discovered as a result of repented experience.

Recall Hume's famous criticism of efforts to prove causal connections in an induotive or empirical manner. No matter how many times observe one sort of thing, $A$, to follow another sort of thing, $B$, there is no absolute assurance that the next time we observe an A It w1ll be followed by a $B$. No necessity of connection is to be observed between $A$ and $B$, and no number of repetitions of this sequence will make up for this conspicuous absence. Hence, Hume could clalm that there is an element of uncertainty with Iespect to any empirical law. (Ve wight better call them "empirical generaliations," for they are based only on observed instances). He could further clatm that the very existence of empirical laws is uncertain. What made this clain significant was the fact that the opposite was assumed by the empirical sciences as a working hypothesis. But Hume did not stop here. He 
clalmed further that no causal connection at all could be demonstrated with absolute certainty to exist. And he also claimed the very idea of causal ity was derived from experience. Now scholars life to present Kent's thought on causality in terms of a response to Hume's thought, and, to a certain extent, Kant intended it as such.

Kant definitely stands opposed to Hume's clain that the ldea of causality is derived from experience. But even here there is not as much clash as one might think. Hume was concerned with the psychological assertion that we come to have the ldea of "cause" as a result of the repeated observation of certain sequences of events. Kant was concerned with the philosophical assertion that the idea of causelity 1s presupposed by: the very notion of a sequence, hence, is presupposed in experience from the very beginning. But this does not commit Kant to the position that one is explicitly conscious of the idea of causallty ${ }^{1}$ from the very beginning, or ever, for that matter. For Kant, the issue at hand was logical, not psychological.

With respect to Hume's claim that no causal connection could be establishied with certainty, we may say from a Kantian point of view, that he overstated his case. Kant's claim that a certain causal connection makes possible the existence of an objective succession in no way mitigates against Hume's claim that the empirical generalizations of "sclence" are all uncertain, and furthermore, that the working hypothesis of "sclence" (that every event has as 1ts cause some

H. J. Paton, Kant's Metaphysic of Experlence, (New York: The Macmillan Company, 1936), Vol. I, pp. 377-8. 
antecedent event) lacks demonstrated objective validity. As Prof.

Buchdahl states:

"Confusion is for instance easily created by an expression like 'nature is subject to law,' Normally this denotes our believe. in the universal prevalence of the realm of determinisin or, less sweeping, of the possibility (at least in principle) of everything being subject to natural laws. It is however quite clear that the argument of the Second Analogy does not support such conclusions. For according to this, the expression 'nature is subject to universal laws' refers to nature regarded as a collection of objective states of affairs, and only means that the possibility of each of these states presupposes the injection of the concept of an indeterminate causal nexus, However, such a situation might be quite compatible with the absence of $a_{2}$ network of empirical laws, or any laws whatsoever." ${ }^{2}$

To end, we must warn against the temptation to regard mental

atates, themselves as subject to causal 1aw. Note, for example, what

N. K. Sinth says:

"The Second Analogy, though crabbedly, diffusely, and even confusedly stated, is one of the finest and most fer-reaching pleces of argument in the whole Critique. It is of special historical importance as being Kant's answer to Hume's denial of the validity of the causal principle. Hume had maintained that we can never be consclous of anything but mere succession. Kant in reply seeks to prove that consciousness of succession is only possible through consclousness of a necessity that determines the onder of the successive events."

Smith's sumation is apt to mislead one with respect to the question of purely subjective, or mental successions. We have, indeed,

'Gerd Buchdahl, "The Kantian "Dynamic of Reason," In Kant Studies Today, I. W. Beck editor, (LaSalle; IIIInols: Open Court Publishing Co., 1969), pp. 356-7.

3N. K. Smith, A Commentary to Kant's Critique of Pure Reason, (New Yorks Humanities Press, 1950), P. 364. 
comitted ourselves to the contention that the 1 dea of necessary connection is involved in the consciousness of subjective succession. But we are not thereby committed to the contention that the subjective states, themselves, are necessarily connected. We argued that consciousness of metital states 28 successive involved the ldea of time as empirically real. We then argued that the empirical reality of time required the empirical reality of matter, and, finally, that the possibility of matter requires the concept of causality. Though it is true then, that consciousness of inner succession involves the idea of causelity it is neither stated nor implied that mental phenomena, themselves, are necessarily connected. Moreover, if the idea of necessary connection is essential to the distinction between 2 subjective and an objective succession, it would seem quite obvious that if it applies to one, it would not apply to the other. The concept of causality is essential to the idea of objective succession and is. presupposed in the consciousness of a subjective succession only because the lidea of objective succession is, itself, presupposed. The "Second Analogy" is concerned with the necessary condition of the possibility of an experlence of alteration of substance. Kant makes it quite clear in the "Parallogisms" that the succession of mental states cannot be legitimately regarded as constituting the 2lteration of a substance. 


\section{BIBLIOGRAPHY}

Beck, I. W. (Ed1tor). Kant Studies Today. LaSalle, IIIino1s: Open Court Publ1shing Company, 1969.

Bennett, Jonathan. Kant's Analytic. Gambridge: Cambridge University Press, 1966.

\section{Pres8, 1974.}

Caind, Ddward. The Crit1cal Philosophy of Immanuel Kant. New York: Kraus Reprint Co., 1968, 2 vols.

Joseph, H, H. B. A Comparison of Kant's Ideal Lsm with That of Berkeley. London! Humphrey Milford Amen House, E.C., I929 (Paper from the Proceedings of the British Academy, Volume XV).

Kant, Immanuel. Critique of Pure Reason. Translated by rorman Kemp Smith. Now York: St. Hartin's Press, 1965.

- Introduction to Logic. Translated by Thomas Kingsmill Abbott. Westport, Connecticut: Greenwood Press, 1972.

Metaphysical Foundations of Natural Science. TransIated and Introduction by James EIIIngton. New York: The Bobbs-herr111 Company. Inc., 1970.

- Prolegomena to Any Future Metaphysics. Edited, Transleted, and Introduction by $L$. W. Beck. New York: The BobbsPerrili Company. Inc., 1950.

Paton, H. J. Kant's Metaphysic of Bxperience.' New York: The Macmilian Company, 1951. 2 vols.

Smith, A. H. Kantion Studies. London: Oxford University Press, 1947.

Smith, N. K. A Commentary to Kant's Eritique of Pure Reason'. New York: The Humanties Press, 1950.

Strawson, $P . F$. The Bounds of Sense. Iondon Methuen \& Co Itd, 1966.

- Individuals. London: Methuen \& Co Ltd. 1961.

Walsh, W. H. Reason and Experience. London: Oxford University Press, $1 9 \longdiv { 4 . }$ 
Nolff, R. P. (Editor). Kant. Garden City, New York Doubleday \& Company, Inc., 1967. 